\title{
Start-up Initiative
}

\author{
Akanksha Dutta ${ }^{1}$ \\ ${ }^{I}$ (Research Scholar, Maharishi Markandeshwar University, Sadopur, Ambala, India)
}

\begin{abstract}
This research paper revolves around the concept of Start-up India Campaign which was started on $15^{\text {th }}$ august,2015. The basic purpose of this article is to put some light on the start-ups and the initiative taken by the Indian govt. The start-ups are the kind of companies which are innovative in their course of development, analysis, evaluation, research for the target segment. In this paper various govt policies, plans, schemes and strategies related to start-ups will be discussed. Start-up is one of the scorching event this era which everyone is talking about. This campaign is particularly based on enhancing the bank financing for the start-ups to encourage the entrepreneurship and job availability.
\end{abstract}

Keywords- entrepreneur, govt plans, initiatives, strategies, success stories.

\section{INTRODUCTION}

Since last few months everybody is talking about the start-ups. Even many events has been organized regarding the same. Basically Start-up is a refined and renewed form of an entrepreneur. It is a juvenile organization that has just started to emerge .It can be new entrepreneurial venture or a new business or a new partnership firm designed to reach for a climbable business model .On $15^{\text {th }}$ August 2015,PM Narender Modi announced this initiative at the Red Fort as Start-up India and on $16^{\text {th }}$ jan 2016 it was officially flagged by Finance minister Arun Jaitley. In this campaign the main aim of the govt is to provide maximum help and support for the new emerging businesses and ideas. The support will be in the form of finance, technology, economic, social as well as environment.

As it is a known fact that when someone starts a new enterprise or tries to get into entrepreneurship they face many problems like finance, land permissions, environmental clearance, foreign investment proposals, family support etc. It is one of the much needed initiative plan of Govt of India. This initiative focuses on filling the gap in the economy and its development and has the objective to fire the entrepreneurial blood at the bottom level. It has brought lot of positivity and confidence among the entrepreneurs of India. According to PM Narender Modi the start-ups, its technology and innovation is exciting and effective instruments for India's transformation.

An idea can be converted into a start-up. Even sometimes the crisis becomes the opportunity and it gives birth to the start-ups. Many times we have seen that we have an idea but we do not dare to initiate it or we do not find it worthy. On the other hand other people take that idea as an opportunity and mobilise into reality. The main objective of the govt is to reduce the load on the start ups hence allowing them to concentrate fully on their business and keeping the low cost of adherence.

\section{REVIEW OF LiteratURE}

It has become increasingly clear in recent years that the conceptualization of leadership must be broadened beyond that of top-down heroic leadership (Day et al., 2004; Pearce, 2004; Yukl, 2002).Shared leadership process append considerable awareness into the staging of the entrepreneurship. It is important for the expansion and extension of new start-ups.According to Ensley, Hmieleski and Pearce(2006) the descriptive value of shared leadership goes over the vertival leadership. This suggest that the high profile cases of the reckless start-ups, whose separate creativity and innovation has led to the renown and destiny, are more folk tale than the actuality. 
Bosma, Praag, Thurik and Wit (2002) has presented a detailed study of firms investing in the human and social capital for improving the performance. They also explained that one cannot be sure about the favourable aspect is due to investing or somewhat due to the innovative entrepreneurs put more in their human and social capital. They also found that the individual entrepreneur who are more skill full in the industry perform better than the others. And finally, they conclude that investing in human and social capital increase the entrepreneurs performance.

Sharma, (2013), made a study on women entrepreneurs in India. She concluded that women entrepreneurs face many problems like social barriers, legal aspects, lack of education, family support etc. She also explained the various factors like pull and push factors affecting entrepreneurship. According to her women have the probable and firmness in setting up the enterprise and fighting against the all odds.

Goyal,Parkash,(2011), in their research paper concluded that at present the position of entrepreneur is better than before. Economies are taking the efforts to make and enhance the entrepreneurship. Government is providing the awareness and necessary steps are being taken up by them. Start-ups must be configured properly with the business expertise to encounter the latest trends and changes in the environment and capable enough for aspiring the supremacy in the entrepreneurial coliseum.

Caliendo,Kunn,Wiebner and Hogenager(2015), finds the difference between subsidized start-ups out of unemployment and non subsidized start-ups out of non employment. It reveals that the initiator of the subsidized start-ups have no lack of conventional education. Although they have less employment and less exposure to the industry.And finally they concluded that the wealth stock restriction among the unemployed in respect to availability of personal equity and out break of loans is the major constraint.

\section{MeThOdology ANd OBJeCtives}

The study is based on the secondary data which has been collected through websites, newspapers, magazines, govt reports, books, research papers etc. The study is based on following objectives:

1). To study the reasons for starting a business.

2).To study the influence of govt cooperation.

3).To study the various policies, programs, agencies involved in enhancing the start-ups.

4).To analyse the important problems faced by the start-ups.

\section{REASONS BEHIND SETTING UP A START-UP}

There are various reasons behind setting up the start-ups. Few but the important reasons for setting the start-up are as follows:

1). Monetary gains-Everyone wants more and more money. And the best way to get it by having your own business. In the job one gets the fixed amount of salary but in own business one can get monetary gains as per his choice.

2). Secured job-Job security is one of the basic need of human beings and it is also referred in the Maslow need hierarchy theory. If job is not secured one cannot work with full zeal. And on the other hand when one works in the business with the tag of a owner the zeal and enthusiasm comes automatically and the job is secured.

3). Job creation-When any entrepreneurship is started people tend to create jobs for others also. An individual can start a business but cannot run it alone. So the opportunity of jobs being created. 
4). Own brand-It always feel good when one tells the other person that the particular brand belongs to him or he is the owner of that developing brand. It gives immense pleasure to introduce yourself as an entrepreneur.

5). Quality of life-Due to the impact of globalisation and e-commerce everyone wants to be at ease and desires to the best quality of life. Being as an owner one has the freedom to choose the life accordingly.

6). Be your boss-Its good not to have a boss. In the business your are not answerable to anyone accept yourself.

7). Converting vision into reality-Everyone has a vision but very less people turn it into reality. While owing an entrepreneur you can convert your vision into reality.

8). Pride-It is a thing of pride when you introduce yourself as the owner of the start-up or an entrepreneurship.

9). Recognition-It is also a need which comes under the need hierarchy theory(Maslow,1943). Every single person wants fame and recognition. And business provides the same.

10). Economic independence-Having more money its ones decision where to put that money. One has the more economic independence.

11). Changing the world-Every time we talk about changing the world with lots of ideas but we never take the initiative to do so. People who take the initiative can change the world according to them, if not the world till they make a difference.

12). Learning different forte-Once you start the business you learn lot many skills which were earlier not the part of your personality. Some skills are the demand of the business and some skills are the demand of the personality.

13). Establishing your dreams-We all have dreams but we never share them with anyone because we fear that people will laugh on us. But there are some people who rise above this laughter and fulfil their dreams.

14). Social responsible-When you have the economic independence you can always choose where you want $t$ spend your money. And generous people are always socially responsible. If one wants to help the humanity than the socially responsible start-ups come in the play.

15). Share talent-During the jobs we are not able to showcase our talent. But once we are into the business we can show our talent and the creativity to the world.

16). Own decisions-Right or wrong, whatever the decision is-one is responsible for that. Right decisions boost up the energy and wrong decisions make people learn the lessons of the life.

17). Legacy-Nowadays the competition is tough and in the coming future there will be less jobs for the future generation. So its very important to keep the legacy going on.

18). More socially involved-Some people are very much socially involved. They love making friends and networking. This helps in the promotion of any start-up and even can link to start a new business.

\section{ROADLOCKS FACED BY THE START-UPS}

Starting an entrepreneurship is not an easy task. There are many factors which influence the initial stage of the start up. When someone starts a new enterprise or tries to get into entrepreneurship they face many problems like finance, land permissions, environmental clearance, foreign investment proposals, family support, team, marketing strategy, legal aspect, resource allocation, mentorship, accurate advice and information, fear of failure etc.

\section{STEPS TAKEN BY THE GOVERNMENT}

The govt plays an important role for establishing the new enterprises. The plans, policies, initiatives, strategies of the govt affect the entrepreneurs. Following are the 19 plans as an initiative for start ups: 
1). Self certification: The main objective of the govt is to reduce the load on the start ups hence allowing them to concentrate fully on their business and keeping the low cost of adherence. It will include labor laws and environment related laws.

2). Start-up India hub: A single contact point will be created for the start-ups in India, which will enable them to exchange knowledge and access to funds.

3). Register through app: An online portal, will be available in the form of a mobile application, which will help entrepreneurs to interact with the govt and other regulatory officials.

4). Patent protection: A monitoring system for patent inspection at reduced costs is being created by the central government. It will enhance perception and acquisition of the Intellectual Property Rights (IPRs) by the entrepreneurs

5). Rs 10,000 crore fund: The government will develop a pool with a starting aggregation of Rs 2,500 crore and a total aggregation of Rs 10,000 crore over four years, to help new entrepreneurs. The important role will be played by the Life Insurance Corporation of India in blossoming this collection. The fund will be managed by a group of professionals selected from the start-up industry.

6). National Credit Guarantee Trust Company: A National Credit Guarantee Trust Company (NCGTC) will be created with a budget of Rs 500 crore per year for the next four years to help the drift of funds to entrepreneurs

7). No Capital Gains Tax: Investments through venture capital funds are exempted from the Capital Gains Tax. The same policy will be executed on start-ups.

8). No Income Tax for three years: Start-ups would not pay Income Tax for the first three years. .

9). Tax exemption for investments of higher value: In case of ventures of higher amount than the market price, they will be exempted from paying tax.

10). Building entrepreneurs: Creative study plans for students will be implemented in over 5 lakh schools. Apart from this, there will also be an annual businessman grand provocation to develop high class businessmen.

11). Atal Innovation Mission: This Mission will be propelled to revitalize ideas and motivate creative youngsters.

12). Setting up incubators: A private-public partnership model is being considered for 35 new incubators and 31 innovation centres at national institutes.

13). Research parks: The government plans to lay seven innovative research parks, including six in the Indian Institute of Technology campuses and one in the Indian Institute of Science campus.

14). Entrepreneurship in biotechnology: The government plans to construct 5 advanced biotech nests, 50 advanced bio incubators, 150 technology transplant offices and 20 bio-connect offices in the country.

15). Dedicated programs in schools: The government plans to inculcate transformational programs for scholars in over 5 lakh schools.

16). Legal reinforce: A committee of moderators will give legal help and reinforcement in complying patent applications and other papers.

17). Rebate: An exemption value of 80 percent of the total value will be given to the start ups on filing the patent applications.

18). Easy rules: Sstandards of communal acquisition and mandate of switching have been easier for the entrepreneurs.

19). Faster exit: If an entrepreneur is unsuccessful than the government will help him to get a particular resolution for their complication.

\section{SUCCESSFUl LEADING START UPS In INDIA}

In last one year India has seen many start-ups, which helped in the growth of the economy. In every sector like retail, hotel industry, medicine, education, transportation etc, start-ups emerged like a boom. Few of 
the leading start-ups are Flipkart, Oyo Rooms, Chaayos, Ola cabs, Paytm, Redbus, Zomato, Zivame, Justdial ,Pepperfry, LImeroad, Quikr, Cardekho, Practo, Urbane ladder, policybazar, Grofers, Shopclues, Nearbuy, Voonik, Inmobi, Firstcry, Yepme, Mobikwik, Bigbasket, Nykaa, Hopscotch, Bluestone, Caratlane, Paperboat, Gojavas, Craftsvilla, Roposo, Voylla, Babyoye, Naaptol etc.

\section{CONCLUSION}

At present day, start ups are growing like a grapevine. Both male and females are getting into it. Even females are coming with more ideas and they are taking the risk to sustain their credibility. Indian start-ups attempt to build the start up environment with important education, talent, innovation and incubators with correspondence to funding agencies. Now the govt is also supporting the Start-ups. According to Nasscom, India ranks third in global start-up ecosystem. More than 65\% growth is seen in the year 2015.Start-up is an opportunity for an entrepreneur to educate and inspire others while some are thinking of how to do and what to do. Although, entrepreneurs are facing problems but still they are rising like a sun. They have the determination to setup and divert their energy to plan, support and execute their dreams and contributing to the growth of the economy. This new initiative of start-ups pledge rapid approvals for starting the business, easier exits, tax rebates and faster registration for the patents. This initiative holds the potential of creating the jobs when the manufacturing sector is having a downfall. For any new idea to become successful venture it requires appropriate support and mentoring.

\section{REFERENCES}

[1] Y. Sharma, "Women entrepreneur in India", IOSR Journal of Business Management, 15(2), 2013.

[2] M. Goyal and J. Prakash, "Women entrepreneurship in India-problems and prospects", Zenith International Journal of Multidisciplinary Research,1(5), 2011.

[3] M.D. Ensley, K. M. Hmieleski and C. L. Pearce, "The importance of vertical and shared leadership with in new venture top management teams: Implication for the performance of the startups", 2006.

[4] N. Bosma, M. V. Praag, R.Thurik and G. D. Wit, "The value of human and social capital investment for the business performance of start-ups", 2002.

[5] M. Caliendo,S. Kunn,F. Wiebner and J. Hogenacker, "Subsidized start-ups out of unmployment :A comparison of regular business start-ups, IZA Discussion Papers”, 8817, 2015.

[6] S. P. Robbins, Organizational Behavior, Motivation concepts, (India :Pearson Education, 2009), 194.

[7] https://en.wikipedia.org/wiki/Start-up_company

[8] https://en.wikipedia.org/wiki/Start-up_India

[9] http://www.iisermohali.ac.in/Start-upIndia_ActionPlan_16January2016.pdf

[10] https://www.speakingwalls.in/blogs/speaking-walls/85632515-eight-challenges-faced-by-an-indian-start-up

[11] http://www.iamwire.com/2015/10/biggest-roadblocks-faced-start-ups-india/124312

[12] http://indiatoday.intoday.in/education/story/start-up-india-stand-up-india/1/573128.html indiatoday.in new delhi, 2016.

[13] http://yourstory.com/2015/12/india-100-top-start-ups-2015/

[14] startups.in/sights/on-getting-published/

[15] http://www.indianstartups.com/

[16] indianexpress, 2016

[17] thehindu, 2016 